\title{
Encouraging of embryo development and seed germination in Actaea racemosa L. by gibberellic acid
}

\author{
I.M. Pinker, T. Degischer, A.-Chr. Rath and R. Schenk \\ Humboldt-Universität zu Berlin, Albrecht Daniel Thaer-Institute, Germany
}

\begin{abstract}
Summary
Actaea racemosa L. (syn. Cimicifuga racemosa (L.) Nuttal) or black cohosh is a perennial plant of the buttercup family (Ranunculaceae) growing wild in deciduous forests of North America. Because mature seeds of $A$. racemosa have a rudimentary embryo and exhibit deep simple epicotyl morphophysiological dormancy, germination is a long-lasting process requiring warm-cold stratification. The study has been conducted in 2015-2016 and aimed to develop an efficient germination protocol. For imbibition, graded seeds (1.22-2.5 mm in length) were incubated in tap water or aqueous gibberellic acid solution for 12 hours. The imbibed seeds were kept in darkness at $23^{\circ} \mathrm{C}$ for 4 weeks (warm phase) followed by 4 weeks of incubation at $14^{\circ} \mathrm{C}$ or $7^{\circ} \mathrm{C}$ (cold phase) in darkness or light. Most embryos in mature seeds were developed to the heart stage. They reached after 4 weeks of warm phase the torpedo stage. During the following cold phase, the embryo development was more pronounced in seeds imbibed in gibberellic acid. This promoting effect of gibberellic acid showed a dose-effect response. Application of $2 \mathrm{~g} \mathrm{~L}^{-1}$ gibberellic acid resulted in germination of around $60 \%$ seeds after 4 weeks of cold phase while $1 \mathrm{~g} \mathrm{~L}^{-1}$ gibberellic acid caused germination of up to $20 \%$ seeds. Due to the application of $2 \mathrm{~g} \mathrm{~L}^{-1}$ gibberellic acid to the imbibition solution the germination of most seeds was possible after 8 weeks warm-cold stratification. The observation of the embryo development proved the promoting effect of gibberellic acid, especially during the cold phase.
\end{abstract}

Keywords

Cimicifuga racemosa (L.) Nuttal, epicotyl dormancy, $\mathrm{GA}_{3}$, imbibition, stratification temperature, warm-cold stratification

\section{Introduction}

Actaea racemosa L. (syn. Cimicifuga racemosa (L.) Nuttal) or black cohosh is a perennial plant of the buttercup family (Ranunculaceae) growing wild in deciduous forests of North America (Fischer et al., 2006). Since a long time A. racemosa is well known as medicinal plant used by the Native Americans to treat various diseases and also snakebites (Predny et al., 2006). Nowadays, products from its dried roots and rhizomes are offered especially against climacteric symptoms (ESCOP, 2011; Huang et al., 2015; Henneicke-von Zepelin, 2017). Clinical researches over decades collected data about efficacy and safety of those products (Henneicke-von Zepelin, 2017; Friederichsen et al., 2019). By pharmaceutical studies

\section{Significance of this study}

What is already known on this subject?

- Actaea seeds exhibit deep simple epicotyl morphophysiological dormancy and need warmcold stratification to germinate. Most authors used fluctuating temperatures during warm- and cold phase for some months each. Germination is long lasting (minimum 5 to 6 months). For the effect of gibberellic acid on germination there are only very few and conflicting reports. In these reports, gibberellic acid concentration used was not always indicated or rather low concentrations were applied, e.g., 2-4 $\mathrm{mg} \mathrm{L}^{-1}$. Gibberellic acid was so far applied continuously during warm- and cold phase, respectively.

What are the new findings?

- This is the first report showing the effect of a high concentration of gibberellic acid applied only during imbibition for 12 hours on embryo development during warm- and cold phase. The embryo development was accelerated in samples imbibed in gibberellic acid solution especially during the cold phase. Germination (emergence of radicle and plumule) started in these samples after 7 weeks already. The application of gibberellic acid to the imbibition solution supported the effect of warmcold stratification regarding dormancy breaking and reduced the required stratification time considerably. Four weeks of warm phase $\left(23^{\circ} \mathrm{C}\right)$ followed by 4 weeks cold phase $\left(14^{\circ} \mathrm{C}\right.$ or $\left.7^{\circ} \mathrm{C}\right)$ were sufficient to get around $60 \%$ germination after 8 weeks already. The germination continued during the following 2 weeks and the percentage of germinated seeds increased.

What is the expected impact on horticulture?

- Actaea racemosa is a valuable medicinal plant used in phytotherapy, especially against climacteric symptoms. Field production for A. racemosa should be established to substitute its harvest from the wild. However, young plant production is still the bottleneck for field production. With this protocol, young plant production can be accelerated considerably and moreover, young plants can be produced in time effectively in large amounts for field production.

action mechanisms of the active substances as triterpenoids and polyphenols are investigated more in detail. It seems, e.g., that some triterpene glycosides may suppress growth of breast cancer cells (Einbond et al., 2008). As plants for drug production were mostly harvested from the wild, concerns 
about over-collection and diversity losses initiated attempts to field cultivation leading consequently to research activities from the 1980s on (Craker et al., 2003; Albrecht and McCarthy, 2007). Researchers as Popp et al. (2003), Fischer et al. (2006), Albrecht and McCarthy (2007), McCoy et al. (2007), and Kaur et al. (2013) stressed the necessity to develop cultivation systems to protect the wild populations. There were also reports on forest farming, but these results were not promising and depended largely from the environmental conditions (Small et al., 2014). Up to now, field cultivation of black cohosh is still hampered by the plant availability. The main problem for young plant production is the seed dormancy in black cohosh. Therefore, alternative clonal propagation techniques were applied as root stock division (Fischer et al., 2006; McCoy et al., 2007), in vitro multiplication (Lata et al., 2002), and somatic embryogenesis (Pinker and Schenk, 2018). Though, seed propagation would be the cheapest method guaranteeing also a certain genetic diversity in the cultivation area.

A. racemosa is characterized as other members of the Actaea genus (Fu et al., 1998; Li and Chen, 2002) by a rudimentary embryo in mature seeds measuring about $0.34 \mathrm{~mm}$ in length (Martin, 1946). According to Baskin and Baskin (2014) this species exhibits deep simple epicotyl morphophysiological dormancy, a type of morphophysiological dormancy (MPD). In nature, radicles of those seeds emerge in autumn while epicotyls or shoots require chilling to break its dormancy and they emerge in late winter or early spring (Baskin and Baskin, 1998). The critical temperatures for warm phase are mentioned to be $\geq 15^{\circ} \mathrm{C}$ and for cold phase $0-10^{\circ} \mathrm{C}$ in moist seeds (Nikolaeva, 1977; Hidayati et al., 2005). In seed technology warm-cold stratification is used for such seeds and application of gibberellic acid $\left(\mathrm{GA}_{3}\right)$ can sometimes help to break the dormancy (Baskin and Baskin, 2004).

Only few reports are available for stratification effects in Actaea. Baskin and Baskin (1985) applied fluctuating temperatures (daily maximum and minimum temperatures: $20.7^{\circ} \mathrm{C} / 8.6^{\circ} \mathrm{C}$ for warm phase and $14.1^{\circ} \mathrm{C} / 4.5^{\circ} \mathrm{C}$ for cold phase). After 8 months they found that more than $80 \%$ of seeds germinated. Popp et al. (2003) investigated various temperature regimes but worked with non-fluctuating temperatures. They applied 1-6 weeks' warm phase at $25^{\circ} \mathrm{C}$ followed by 8 weeks of cold phase at $12^{\circ} \mathrm{C}$ with a later change to $25^{\circ} \mathrm{C}$ again. Popp et al. (2003) published that in total 12 weeks were necessary for radicle emergence and concluded for the temperature regime that $C$. racemosa seeds require at least 4 weeks' warm phase followed by a cold phase. Albrecht and McCarthy (2007) applied 12 weeks fluctuating temperatures at $15 / 6^{\circ} \mathrm{C}$ followed by 12 weeks at $5^{\circ} \mathrm{C}$. They concluded that at least 8 weeks for cold phase are necessary to break the physiological dormancy. Kaur et al. (2013) studied 15 Actaea accessions and applied two methods to break the dormancy under in vitro conditions. In the two-step-approach for 2 weeks, $25^{\circ} \mathrm{C}$ were applied in darkness followed by alternating temperatures $\left(20^{\circ} \mathrm{C} / 8^{\circ} \mathrm{C}\right)$ for 12 -h periods within a 16 -h photoperiod for 12 months. The three-step-approach started also with $25^{\circ} \mathrm{C}$ for 2 weeks, but for the next $3-4$ months $4^{\circ} \mathrm{C}$ were applied in darkness. The seeds with emerging radicle and shoot were transferred to $25^{\circ} \mathrm{C}$ into light (third step). With the three-step-approach higher germination percentages (up to $80 \%$ ) were reached and germination was accelerated with radicle emergence within 4 months and shoot emergence after around 6 months.

Application of $\mathrm{GA}_{3}$ may promote seed germination in some types of MPD (Baskin and Baskin, 2004). In five species with deep simple epicotyl MPD there are reports that $\mathrm{GA}_{3}$ substituted at least partly temperature effects during stratification by supporting the embryo growth (Baskin and Baskin, 2014). In Fraxinus excelsior, $1 \times 10^{-3} \mathrm{M}$ or $5 \times 10^{-3} \mathrm{M} \mathrm{GA}_{3}$ applied from the imbibition till the end of stratification at high (17$24^{\circ} \mathrm{C}$ ) or low $\left(4-6^{\circ} \mathrm{C}\right)$ temperatures accelerated the embryo growth (Wciślińska, 1977). In both temperature conditions the higher embryo size was reached with $\mathrm{GA}_{3}$ application after 12 weeks. Warm-cold stratification without gibberellic acid treatment resulted also in embryo growth and 60\% seed germinated after 40 weeks. By application of $\mathrm{GA}_{3}$ in cold stratification, however, seed germinated after 21 weeks already. Wciślińska (1977) concluded that $\mathrm{GA}_{3}$ accelerates the embryo growth by breaking the first kind of dormancy but is not responsible for breaking the physiological dormancy, for which cold stratification is required. In Cardiocrinum cordatum $0.1 \mathrm{~g} \mathrm{~L}^{-1} \mathrm{GA}_{3}$ application for 90 days substituted partly the effect of high temperatures regarding embryo development (Kondo et al., 2006). In A. racemosa there are only few and conflicting reports regarding the effect of $\mathrm{GA}_{3}$. Popp et al. (2003) reported that $4 \mathrm{mg} \mathrm{L}^{-1} \mathrm{GA}_{3}$ treatment accelerated somewhat the leaf development in C. racemosa while Kaur et al. (2013) did not find a promoting of $\mathrm{GA}_{3}$ on in vitro germination whereas concentrations used were not indicated. Histo-differentiation of somatic embryos in vitro was encouraged by the application of $\mathrm{GA}_{3}$ up to the torpedo stage, although, further development was rather supported by the application of 6-benzylaminopurine (Pinker et al., 2016). Based on the results reported for other species (Fraxinus excelsior and Cardiocrinum cordatum) it is hypothesized that application of high $\mathrm{GA}_{3}$ concentrations before warm phase supports the embryo development during stratification in Actaea and accelerates hereby the germination.

Effects of $\mathrm{GA}_{3}$ application and growing conditions (temperature and light) on embryo development, dormancy breaking, and seed germination were studied with the aim to force the germination process in A. racemosa.

\section{Materials and methods}

\section{Seed and embryo quality in mature seeds}

The mature follicles (fruits) were harvested in September 2015 from plants propagated through rhizome division and established in a research field in Berlin-Dahlem (Germany). Each follicle had 8-12 seeds (half-moon shaped, lens shaped, or round) (Figure 1a) arranged in two rows. The seed colour ranged from light to dark brown. Seeds were stored for 6 weeks in $45 \%$ air humidity at $18^{\circ} \mathrm{C}$. After seed purification the seeds were graded through sieving. First, they were sieved with mash size of $1.4 \mathrm{~mm}$ and then with mash size of $2.0 \mathrm{~mm}$. Remaining seeds were evaluated visually and dead or broken seeds were eliminated.

The mean thousand seed weight was determined in 8 graded seed samples of 100 seeds each according to the ISTA rules (ISTA, 2018). Length and width of air-dry seeds were determined by measuring 60 seeds of the graded seed samples. The length was measured along the flat seed side including the ridges. Seed width was recorded at the widest lateral dimension from flat side to the arched side.

The embryo developmental stage of 90 embryos isolated from mature imbibed seeds (1.8-2.2 mm long) was evaluated. Their longitudinal and lateral dimensions were measured under the dissection microscope (Vision Cobra, Vision Engineering). 

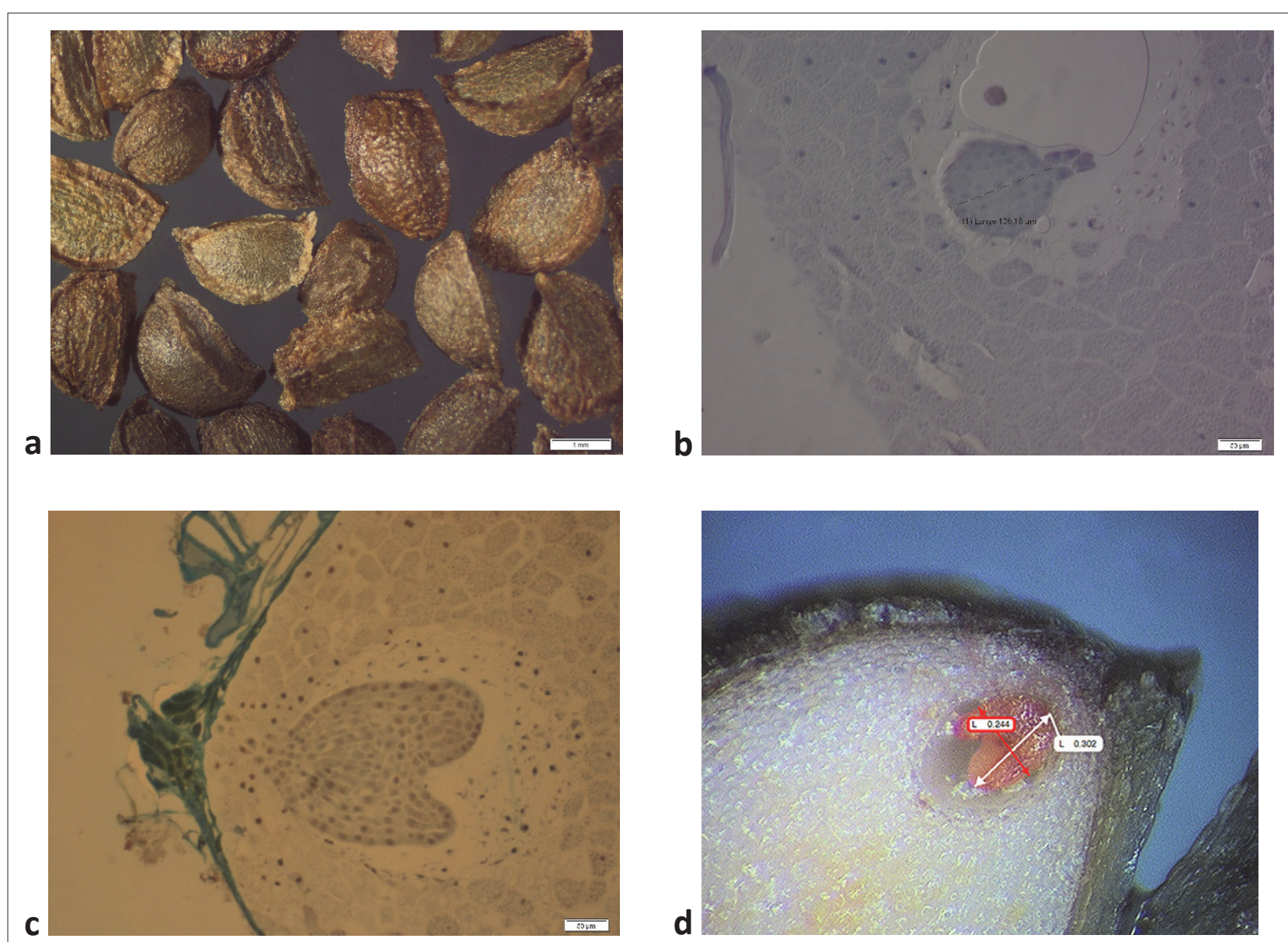

FIGURE 1. a: Seed sample used for dissection (view in dissection microscope); b: Globular embryo with suspensor in mature seeds (view through transmission light microscope); c: Heart stage embryo with suspensor in mature seeds (view through transmission light microscope); d: Heart stage embryo (view in dissection microscope), length and width (L in $\mathrm{mm}$ ).

\section{Embryo evaluation methods}

Embryo viability was evaluated with TZ-test according to ISTA (2018). The seeds were halved with a razor blade and a $1 \%$ aqueous solution of 2,3,5-triphenyltetrazoliumchlorid (TZ), $\mathrm{pH}$ 6.5, was dropped on the embryo. After one hour at $30^{\circ} \mathrm{C}$ the color of the embryos was observed and their dimensions measured under the dissection microscope (Vision Cobra, Vision Engineering).

For more detailed analyses transmission light microscopy was used. The embryo development after harvest and during warm and cold phase had been observed in seeds fixed in FAA (formalin: glacial acetic acid: 50\% ethanol, $5: 5: 90, \mathrm{v} / \mathrm{v} / \mathrm{v}$ ) for $48 \mathrm{~h}$. After fixation the specimens were dehydrated with a graded series of alcohol and then embedded in the plastic resin Technovit $7100^{\circledR}$ (Hereaus Kulzer GmbH \& Co. KG, Wehrheim, Germany). Cross-sections (5 $\mu \mathrm{m}$ thick) were stained with Toluidine Blue $0(0.05 \%)$ and a tincture of iodine/potassium iodide and then examined under a microscope (Olympus BH-2). Pictures of 30 embryos per treatment and week were taken with the Olympus UC30 camera and analyzed with cellSens Entry 1.6 software of Olympus.

\section{Determination of water uptake during imbibition}

To determine the water uptake time-course during imbibition, 40 samples with 3 g air-dry seeds (DW) each were filled into 50-mL glass bottles and incubated in $10 \mathrm{~mL}$ tap water or aqueous $2 \mathrm{~g} \mathrm{~L}^{-1}$ gibberellic acid $\left(\mathrm{GA}_{3}\right.$, Roth) solution at $22^{\circ} \mathrm{C}$ on a rotation shaker $(100 \mathrm{rpm})$ for $7 \mathrm{~h}$. The first weight record on a precision balance $(150 / 0.000$ g Sartori- us Laboratory) was done with $2 \times 2$ samples after $5 \mathrm{~min}$ incubation in tap water and $2 \mathrm{~g} \mathrm{~L}^{-1} \mathrm{GA}_{3}$-solution, respectively. The seeds were incubated in tap water and $\mathrm{GA}_{3}$-solution, respectively, and at hourly interval, for $7 \mathrm{~h}$ long, two seeds samples per treatment were weighted. Before weighting the incubated seed samples were collected in a sieve to drip the incubation solution. After that, the seeds were enwrapped in filter paper to suck the free water from seed surface and now the imbibed seed weight (IW) was determined. The water uptake was calculated as $\%$ water uptake $=(I W-D W) * 100 /$ DW.

Evaluation of embryo development during stratification Air-dry seed samples, $100 \mathrm{~g}$ each, were first pre-treated with a seed protectant solution (CELEST ${ }^{\circledR}$, Syngenta) and then imbibed at $22^{\circ} \mathrm{C}$ for $12 \mathrm{~h}$ in $250 \mathrm{~mL}$ tap water $\left(0 \mathrm{~g} \mathrm{~L}^{-1}\right.$ $\mathrm{GA}_{3}$ ) or aqueous $\mathrm{GA}_{3}$-solution ( 1 and $2 \mathrm{~g} \mathrm{~L}^{-1}$ ) on a rotation shaker $(100 \mathrm{rpm})$. After that the free solution was separated from seed samples by dripping through a sieve.

The wet, imbibed seeds ( $8 \mathrm{~g}$ per treatment) were incubated on wet filter paper (only tap water) in closed germination vessels for 4 weeks at $23^{\circ} \mathrm{C}$ in darkness (warm phase). After that, cold phase started and seeds were incubated at $14^{\circ} \mathrm{C}$ under a photoperiod of $12 \mathrm{~h}$ daily with $20 \mu \mathrm{mol} \mathrm{m}^{-2} \mathrm{~s}^{-1}$ photosynthetic active radiation, or at $14^{\circ} \mathrm{C}$ and $7^{\circ} \mathrm{C}$, respectively, in darkness. The cold phase lasted for 4 weeks, which means, from week 5 to week 8 . If necessary, during stratification the filter paper was watered with tap water. Details for the seed treatments are described in Table 1 . Weekly 60 seeds per 
TABLE 1. Variants of seed treatments during imbibition as well as warm and cold phases.

\begin{tabular}{|c|c|c|c|c|c|c|c|}
\hline Phase & \multicolumn{6}{|c|}{ Treatment } & Duration \\
\hline Imbibition $\mathrm{GA}_{3}\left(\mathrm{~g} \mathrm{~L}^{-1}\right)$ & \multicolumn{2}{|c|}{0} & \multicolumn{2}{|c|}{1} & \multicolumn{2}{|c|}{2} & 12 hours \\
\hline Warm $\left(23^{\circ} \mathrm{C}\right)$ & \multicolumn{2}{|c|}{ Darkness } & \multicolumn{2}{|c|}{ Darkness } & \multicolumn{2}{|c|}{ Darkness } & 4 weeks \\
\hline Cold $\left(14^{\circ} \mathrm{C}\right)$ & Light & Darkness & Light & Darkness & Light & Darkness & 4 weeks \\
\hline Cold $\left(7^{\circ} \mathrm{C}\right)^{*}$ & & & & & & Darkness & 4 weeks \\
\hline
\end{tabular}

*: alternative to $14^{\circ} \mathrm{C}$.

treatment were randomly taken off and 30 embryos of that sample examined under the dissection microscope (Vision Cobra, Vision Engineering).

\section{Evaluation of seed germination}

After 8 weeks, from each seed treatment a sample of $0.2 \mathrm{~g}$ (between 272 and 313 seeds per treatment) was taken and for all seeds of this sample germination was recorded. Seeds were recorded as germinated when radicle was visible and plumule was fully developed.

\section{Statistical evaluation}

All data were collected as described above and subjected to statistical analyses using IBM SPSS Statistics, v.22. For each sample mean value and standard deviation (SD) was calculated and differences were accepted as statistically significant when $p \leq 0.05$ according to Tukey's test for quantitative data and Chi square test (Pearson) for qualitative data.

\section{Results}

\section{Embryos and mature seeds quality}

The thousand seed weight was $2.72 \pm 0.005 \mathrm{~g}$ for the graded seed lots. Air-dry seeds ranged after grading in length from 1.22 to $2.5 \mathrm{~mm}$ and from 0.94 to $1.5 \mathrm{~mm}$ in width. For seed dissection a subset of half-moon shaped seeds between 1.8 and $2.2 \mathrm{~mm}$ in length were used (Figure $1 \mathrm{a}$ ). The rather small, round shaped seeds and the larger seeds as well were unsuitable for dissection procedure.

After 6 weeks' storage, around $80 \%$ of embryos were stained with TZ and considered therefore as viable. Seeds smaller than $1 \mathrm{~mm}$ in length were empty. Some globular embryos (Figure 1b) were found in mature seeds in the histological observation (Figure $1 \mathrm{~b}$ ) but most embryos inside the dissected seeds were in the heart stage (Figures $1 \mathrm{c}$ and $1 \mathrm{~d}$ ). The embryo size in heart stage embryos of these seed lots was determined with $312 \pm 0.05 \mu \mathrm{m}$ in length and $208 \pm 0.03 \mu \mathrm{m}$ in width.

\section{Determination of water uptake during imbibition}

The seed samples were immersed in tap water and aqueous $2 \mathrm{~g} \mathrm{~L}^{-1} \mathrm{GA}_{3}$-solution, respectively. Already after $5 \mathrm{~min}$ incubation, the seed testa changed its appearance and $2 \mathrm{~h}$ later, these changes were more pronounced. In Figure 2 the time course of water uptake is presented. The seeds weight increased due to water uptake by more than $50 \%$ already after 5 min immersion in the imbibition solutions indicated as hour 0 . After one-hour imbibition the water uptake was between 80 and $90 \%$ of the initial seed weight. After $3 \mathrm{~h}$ the seed weight had doubled (around 100\% water uptake). During the following $4 \mathrm{~h}$ the values were a little bit fluctuating but no further significant weight increase was determined. The values for water uptake were similar for seeds incubated in tap water or $2 \mathrm{~g} \mathrm{~L}^{-1} \mathrm{GA}_{3}$ (Figure 2). The

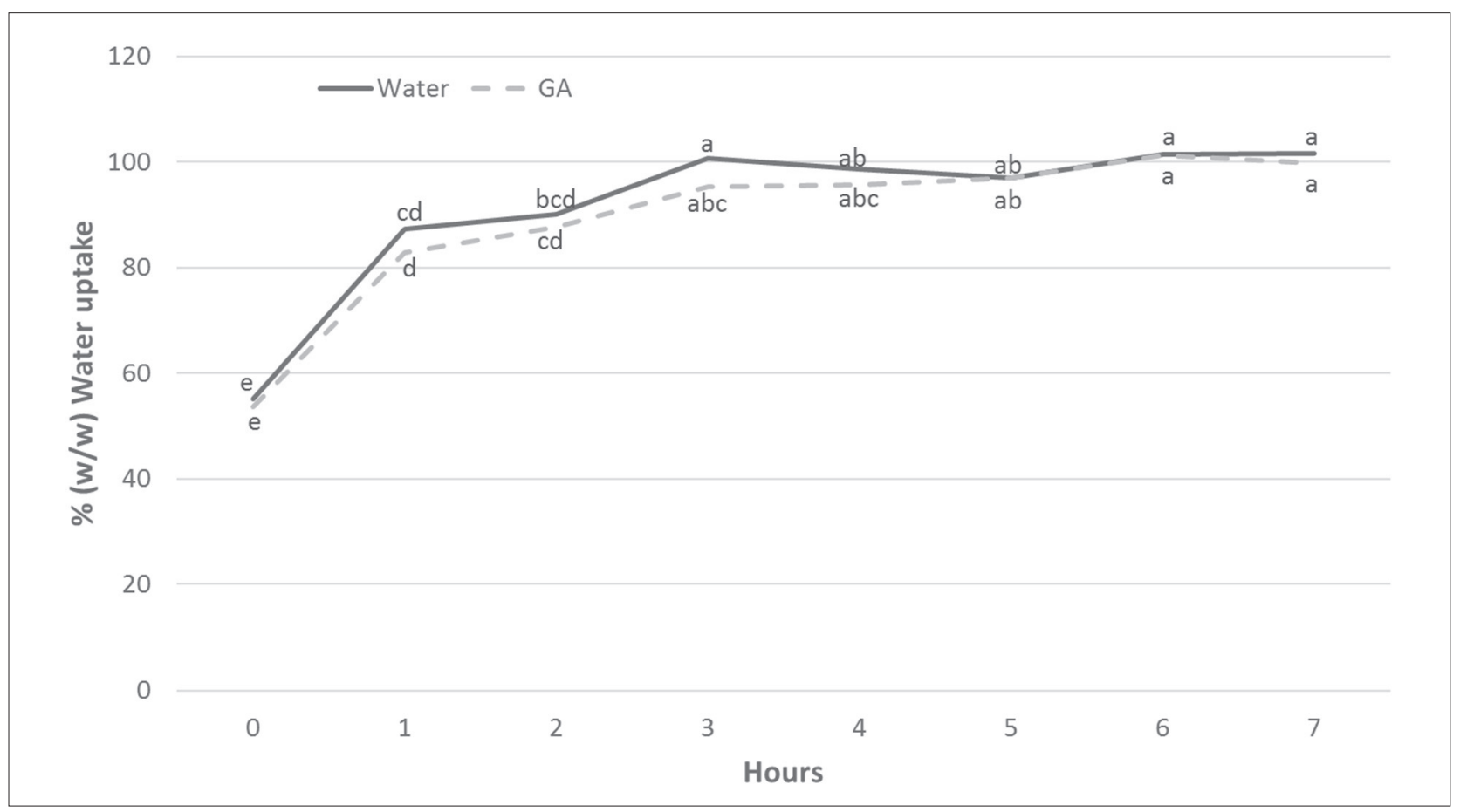

FigURE 2. Uptake of the imbibition solution (tap water or $2 \mathrm{~g} \mathrm{~L}^{-1} \mathrm{GA}_{3}$ solution) calculated based on the weight increase in per cent of seed samples with initially $3 \mathrm{~g}$ air-dry seed samples $(0 \%=$ base line value). The values indicated at 0 hours are the values measured 5 min after immersion. Different letters indicate significant differences according to Tukey's test, $p \leq 0.05$. (See also Supplemental Information, Figure S1). 
TABLE 2. Seed length $(\mathrm{mm})$ during imbibition of graded seed samples $(n=60)$.

\begin{tabular}{lc}
\hline & Seed length* \\
\hline Air-dry & $1.68 \pm 0.19^{\mathrm{c}}$ \\
5 min imbibition & $1.81 \pm 0.12^{\mathrm{b}}$ \\
2 hours imbibition & $1.94 \pm 0.23^{\mathrm{a}}$ \\
\hline
\end{tabular}

*: mean \pm standard deviation.

Different letters indicate significant differences according to Tukey's test, $p \leq 0.05$.

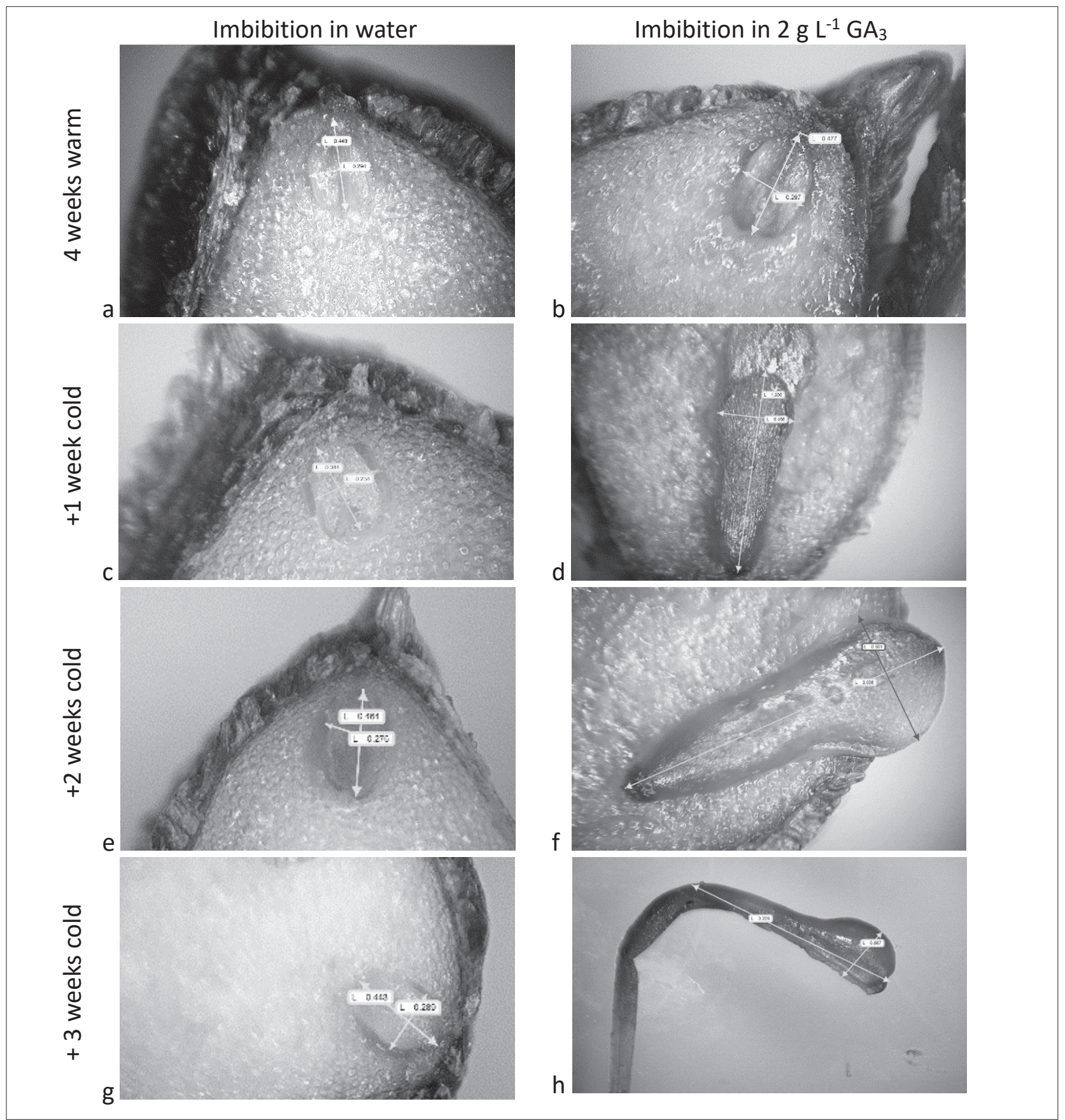

FIGURE 3. Embryo development during warm and cold phase (view through dissection microscope). a: Early torpedo-stage embryo after 4 weeks' warm phase - water imbibition; b: Late torpedo-stage embryo after 4 weeks' warm phase $-2 \mathrm{~g} \mathrm{~L}^{-1} \mathrm{GA}$ imbibition; c: Early torpedo-stage embryo after one week cold phase - water imbibition; d: Early cotyledonary-stage embryo after one week cold phase - $2 \mathrm{~g} \mathrm{~L}^{-1} \mathrm{GA}_{3}$ imbibition; e: Early torpedo-stage embryo after 2 weeks' cold - imbibition; f: Cotyledonary-stage embryo after 2 weeks' cold phase $-2 \mathrm{~g} \mathrm{~L}^{-1} \mathrm{GA}_{3}$ imbibition; g: Early torpedo-stage embryo after 3 weeks' cold phase - water imbibition; h: Germinating embryo after 3 weeks' cold phase $-2 \mathrm{~g} \mathrm{~L}^{-1} \mathrm{GA}_{3}$ imbibition. $\mathrm{L}$ in $\mathrm{mm}$. 
TABLE 3. Effect of $\mathrm{GA}_{3}$ concentration $\left(\mathrm{g} \mathrm{L}^{-1}\right)$ in the imbibition solution on embryo length $(\mu \mathrm{m})$, during warm phase $\left(23^{\circ} \mathrm{C}\right.$, week 1-4) and cold phase $\left(14^{\circ} \mathrm{C}\right.$, week $\left.5-7\right)$ in darkness $(n=30)$.

\begin{tabular}{lccc}
\hline & \multicolumn{3}{c}{$\mathrm{GA}_{3}$} \\
\cline { 2 - 4 } Week & 0 & 1 & 2 \\
\cline { 2 - 4 } & & Embryo length $^{\mathrm{a}}$ & $330.27 \pm 63.14^{\mathrm{d}}$ \\
1 & $295.00 \pm 45.94^{\mathrm{d}}$ & $312.37 \pm 39.55^{\mathrm{d}}$ & $349.93 \pm 52.88^{\mathrm{d}}$ \\
2 & $322.47 \pm 39.34^{\mathrm{d}}$ & $330.80 \pm 30.13^{\mathrm{d}}$ & $414.03 \pm 79.50^{\mathrm{d}}$ \\
3 & $317.77 \pm 52.55^{\mathrm{d}}$ & $340.07 \pm 56.59^{\mathrm{d}}$ & $398.60 \pm 75.05^{\mathrm{d}}$ \\
4 & $327.77 \pm 51.36^{\mathrm{d}}$ & $373.87 \pm 56.66^{\mathrm{d}}$ & $473.60 \pm 83.10^{\mathrm{d}}$ \\
5 & $393.63 \pm 59.66^{\mathrm{d}}$ & $409.00 \pm 47.22^{\mathrm{d}}$ & $1,180.00 \pm 919.18^{\mathrm{c}}$ \\
6 & $348.60 \pm 44.82^{\mathrm{d}}$ & $448.23 \pm 292.13^{\mathrm{d}}$ & $1,720.07 \pm 998.21^{\mathrm{b}}$ \\
7 & $380.03 \pm 56.27^{\mathrm{d}}$ & $1,159.67 \pm 823.34^{\mathrm{c}}$ & $2,485.03 \pm 645.94^{\mathrm{a}}$ \\
\hline
\end{tabular}

*: mean \pm standard deviation.

Different letters indicate significant differences according to Tukey's test, $p \leq 0.05$.

torpedo stage already (Figure 3b). During the warm phase the embryo size seemed to increase, however, showing no significance to statistical analysis (Table 3). The cold phase stimulated the embryo growth (Table 3) and histo-differentiation of the embryos in $\mathrm{GA}_{3}$ treated seeds considerably (Figure 3d). The effect of $\mathrm{GA}_{3}$ depended on concentration. In week 5, embryos treated with $2 \mathrm{~g} \mathrm{~L}^{-1} \mathrm{GA}_{3}$ were around three times longer than embryos after imbibition (Table 3). Embryos of seed imbibed in $1 \mathrm{~g} \mathrm{~L}^{-1} \mathrm{GA}_{3}$ were grown by around $40 \%$, however, this was insignificant compared to water imbibed seeds which increased in length by around $20 \%$ (Table 3). The embryo developmental stage was also affected by $\mathrm{GA}_{3}$ concentration. Many of embryos treated with $2 \mathrm{~g} \mathrm{~L}^{-1} \mathrm{GA}_{3}$ were already in the early cotyledonary stage (Figure $3 \mathrm{~d}$ ) after 5 weeks of stratification. The embryos of seeds imbibed in tap water and $1 \mathrm{~g} \mathrm{~L}^{-1} \mathrm{GA}_{3}$ were rather in the early torpedo stage (Figure $3 \mathrm{c}$ ). In week 6 , the embryos increased considerably in length in samples imbibed in $\mathrm{GA}_{3}$ while those of water imbibed samples did not grow significantly (Table 3;
Figures 3e and 3f). In week 7 embryos of the $2 \mathrm{~g} \mathrm{~L}^{-1}$ treatment continued to grow, exhibited finally a mean length of $2.5 \mathrm{~mm}$ (Table 3) and started to germinate (Figure $3 \mathrm{~h}$ ). The promoting effect of $\mathrm{GA}_{3}$ treatment became now also obvious in the seed treated with $1 \mathrm{~g} \mathrm{~L}^{-1} \mathrm{GA}_{3}$. They reach finally a mean length of around $1.5 \mathrm{~mm}$ (Table 3). In the seed treated with tap water the embryos developed but much slower than in the samples treated with $\mathrm{GA}_{3}$ (Table 3; Figure 3).

Altering the growing conditions during cold phase (lower temperature or light instead darkness) had no effect on the embryo development. The largest embryos were found in week 7 after imbibition in $2 \mathrm{~g} \mathrm{~L}^{-1} \mathrm{GA}_{3}$ regardless the growing conditions (Table 4). The embryo development was not significantly different in light or dark conditions (Table 4).

\section{Germination}

First seeds with radicle emergence (Figure $3 \mathrm{~h}$ ) could be observed after 7 weeks if they were imbibed in $2 \mathrm{~g} \mathrm{~L}^{-1} \mathrm{GA}_{3}$. The promoting effect of treatment with gibberellic acid on

TABLE 4. Effect of $\mathrm{GA}_{3}$ concentration $\left(\mathrm{g} \mathrm{L}^{-1}\right)$ in the imbibition solution and growing conditions during cold phase (temperature and light or darkness) on embryo length $(\mu \mathrm{m})$ in week $7(n=30)$.

\begin{tabular}{lccc}
\hline \multirow{2}{*}{$\mathrm{GA}_{3}$} & \multicolumn{3}{c}{ Embryo length* } \\
\cline { 2 - 4 } & $14^{\circ} \mathrm{C}$, light & $14^{\circ} \mathrm{C}$, darkness & $7^{\circ} \mathrm{C}$, darkness \\
\hline 0 & $392.0 \pm 62.8^{\mathrm{c}}$ & $484.2 \pm 278.5^{\mathrm{c}}$ & n.d. \\
2 & $1,686.1 \pm 935.0^{\mathrm{b}}$ & $1,471.8 \pm 998.2^{\mathrm{b}}$ & n.d. \\
2 & $2,788.5 \pm 600.0^{\mathrm{a}}$ & $2,485.03 \pm 645.94^{\mathrm{a}}$ & $2,414.0 \pm 588.6^{\mathrm{a}}$ \\
\hline
\end{tabular}

*: mean \pm standard deviation.

Different letters indicate significant differences according to Tukey's test, $p \leq 0.05$.

n.d.: not determined.

TABLE 5. The effect of $\mathrm{GA}_{3}$ concentration $\left(\mathrm{g} \mathrm{L}^{-1}\right)$ in the imbibition solution and growing conditions during cold phase (temperature and light or darkness) on seed germination (\%) after 8 weeks' stratification $(n>270)$. (See also Supplemental Information, Figure S2).

\begin{tabular}{lccc}
\hline \multirow{2}{*}{$\mathrm{GA}_{3}$} & \multicolumn{3}{c}{ Seed germination } \\
\cline { 2 - 4 } & $14^{\circ} \mathrm{C}$ light & $14^{\circ} \mathrm{C}$ darkness & $7^{\circ} \mathrm{C}$ darkness \\
\hline 0 & $0^{c}$ & $0^{c}$ & n.d. \\
2 & $0^{c}$ & $19.6^{b}$ & n.d. \\
\hline
\end{tabular}

Different letters indicate significant differences according to Chi square test, Pearson, $p \leq 0.05$.

n.d.: not determined. 
germination was clearly proved (Table 5). Seeds imbibed in water did not germinate at all after 8 weeks. Gibberellic acid treatment resulted in germination of around $20 \%\left(1 \mathrm{~g} \mathrm{~L}^{-1}\right.$ $\left.\mathrm{GA}_{3}\right)$ to $60 \%\left(2 \mathrm{~g} \mathrm{~L}^{-1} \mathrm{GA}_{3}\right)$ after 8 weeks' stratification. During the following 2 weeks the germination process continued. Two weeks later up to $80 \%$ seeds of the $2 \mathrm{~g} \mathrm{~L}^{-1} \mathrm{GA}_{3}$ treatment germinated.

For germination, the growing conditions - light or dark - were not important, however, seedlings developed faster and their cotyledons occurred earlier in light (Supplemental Information, Figure S2).

\section{Discussion}

Compared to literature data, seeds used in these experiments, especially that for dissection (1.8-2.2 mm long), were smaller than those used by Kaur et al. (2013) with $3 \mathrm{~mm}$ long seeds for seed dissection. Albrecht and McCarthy (2007) reported declining viability of seeds during storage reaching around $70 \%$ viability after 6 weeks storage. This is little less than the viability $(80 \%)$ determined in this study. The embryo size in mature seeds was determined with around $312 \mu \mathrm{m}$ in length confirming the value of $0.34 \mathrm{~mm}$ published earlier by Martin (1946). Most embryos were in the heart stage as also reported by Kaur et al. (2013).

Kaur et al. (2013) imbibed the Actaea seeds for in vitro germination experiments for $2 \mathrm{~h}$ while Baskin and Baskin (1985) did not mention an imbibition stage for seeds sown in soil in greenhouse. Based on the current results, 3 to $12 \mathrm{~h}$ in the imbibition solution seems to be recommended.

Regarding the effect of $\mathrm{GA}_{3}$ on embryo development, the current results are in contrast to the results of Kaur et al. (2013) who mentioned that $\mathrm{GA}_{3}$ treatment did not accelerate embryo development, however, they worked in vitro and the applied $\mathrm{GA}_{3}$ concentration was not mentioned. The stimulating effect of $\mathrm{GA}_{3}$ treatment in current experiments can be interpreted in line with the findings in other species regarding substitution of warm temperatures by $\mathrm{GA}_{3}$ (Wciślińska, 1977; Kondo et al., 2006). Using this $\mathrm{GA}_{3}$ effect, the total stratification time could be reduced considerably to 8 weeks compared, e.g., to 5 months reported by Kaur et al. (2013) and even to 12 weeks necessary for radicle outgrowth reported by Popp et al. (2003).

Considering the growing factors influencing the embryo development and germination the most important ones seems to be the temperature. The warm-cold stratification was successful at constant temperatures $\left(23^{\circ} \mathrm{C}\right.$ and $14^{\circ} \mathrm{C}$, respectively) more or less those temperatures as Popp et al. (2003) applied. It seems to be clear that non-fluctuating temperatures may fulfill the requirements for dormancy breaking. But it should be added that 4 weeks' warm phase were only sufficient if $\mathrm{GA}_{3}$ was applied with the imbibition solution. The observations of embryos clearly showed that during 4 weeks' warm phase the embryo development was rather slow. This seems to be in contrast to Baskin and Baskin (2004), who mentioned that warm temperatures are responsible for embryo growth. The effect of $\mathrm{GA}_{3}$ application during imbibition became obvious first in the cold phase. In the literature different temperatures were indicated for cold phase. Baskin and Baskin (1985) worked successfully with $14.1^{\circ} \mathrm{C} / 4.5^{\circ} \mathrm{C}$. Kaur et al. (2013) used alternating temperatures $\left(20^{\circ} \mathrm{C} / 8^{\circ} \mathrm{C}\right)$ while Albrecht and McCarthy (2007) applied constantly $5^{\circ} \mathrm{C}$ in cold phase. In current experiment a temperature of $14^{\circ} \mathrm{C}$ worked very well and was used as standard. Maybe lower temperatures could be also used as shown here with the $7^{\circ} \mathrm{C}$ treatment.
Some authors exposed the seeds during stratification to light (Baskin and Baskin, 1985; Kaur et al., 2013). In the current experiments lighting resulted in the same embryo size as darkness. However, seedling development was better in light than in darkness and therefore this phase should be run in light.

The results confirm the hypothesis that high dosages of $\mathrm{GA}_{3}$ applied before warm phase support embryo development in Actaea. Finally, a very efficient germination protocol was developed for $A$. racemosa. The role of gibberellic acid in dormancy breaking should be considered more in detail later on.

\section{References}

Albrecht, M.A., and McCarthy, B.C. (2007). Effects of storage on seed dormancy and survivorship in black cohosh (Actaea racemosa L.) and goldenseal (Hydrastis canadensis L.). Seed Sci. Technol. 35, 414422. https://doi.org/10.15258/sst.2007.35.2.16.

Baskin, J.M., and Baskin, C.C. (1985). Epicotyl dormancy in seeds of Cimicifuga racemosa and Hepatica acutiloba. Bull. Torrey Bot. Club 112, 253-257. https://doi.org/10.2307/2996540.

Baskin, C.C., and Baskin, J.M. (1998). Germination ecology of seeds with morphophysiological dormancy. In Seeds: Ecology, Biogeography, and Evolution of Dormancy and Germination, C. Baskin, and J.M. Baskin, eds. (Academic Press), p. 87-100. https:// doi.org/10.1016/B978-012080260-9/50005-1.

Baskin, J.M., and Baskin, C.C. (2004). A classification system for seed dormancy. Seed Sci. Res. 14, 1-16. https://doi.org/10.1079/ SSR2003150.

Baskin, C.C., and Baskin, J.M. (2014). Germination ecology of seeds with morphophysiological dormancy. In Seeds: Ecology, Biogeography, and Evolution of Dormancy and Germination, C. Baskin, and J.M. Baskin, eds. (Academic Press), p. 119-143. https://doi.org/10.1016/B978-0-12-416677-6.00005-6.

Craker, L.E., Gardner, Z., and Etter, S.C. (2003). Herbs in American fields: A horticultural perspective of herb and medicinal plant production in the United States, 1903 to 2003. HortScience 38, 977983. https://doi.org/10.21273/HORTSCI.38.5.977.

Einbond, L.S., Wen-Cai, Y., He, K., Wu, H., Cruz, E., Roller, M., and Kronenberg, F. (2008). Growth inhibitory activity of extracts and compounds from Cimicifuga species on human breast cancer cells. Phytomedicine 15, 504-511. https://doi.org/10.1016/j. phymed.2007.09.017.

ESCOP (2011). Cimicifugae rhizoma - Black Cohosh (Exeter: ESCOP).

Fischer, S., Berti, M., Wilckens, R., and Del Pozo, A. (2006). Development of vegetative propagation for Actaea racemosa Nutt. Ind. Crops Prod. 24, 244-252. https://doi.org/10.1016/j. indcrop.2006.06.004.

Friederichsen, L., Nebel, S., Zahner, C., Bütikofer, L., and Stute, P. (2019). Effect of CIMicifuga racemosa on metaBOLIC parameters in women with menopausal symptoms: A retrospective observational study (CIMBOLIC). Arch. Gynecol. Obstet. 301, 517-523. https://doi. org/10.1007/s00404-019-05366-8.

Fu, J., Qi, W.-Q., Gu, Z.-H., and You, R.-L. (1998). Seed dormancy and germination in Cimicifuga nanchuanensis. Acta Bot. Sin. 40, 303-308.

Henneicke-von Zepelin, H.-H. (2017). 60 years of Cimicifuga racemosa medicinal products: Clinical research milestones, current study findings and current development. Wien. Med. Wochenschr. 167, 147-159. https://doi.org/10.1007/s10354-016-0537-z.

Hidayati, S.N., Baskin, J.M., and Baskin, C.C. (2005). Epicotyl dormancy in Viburnum acerifolium (Caprifoliaceae). Am. Midl. Nat. 153, 232244. https://doi.org/10.1674/0003-0031(2005)153[0232:EDIVAC ]2.0.CO;2. 
Huang, H., Sun, J., McCoy, J.A., Zhong, H., Fletcher, E.J., Harnly, J., and Chen, P. (2015). Use of flow injection mass spectrometric fingerprinting and chemometrics for differentiation of three black cohosh species. Spectrochim. Acta, Part B At. Spectrosc. 105, 121129. https://doi.org/10.1016/j.sab.2014.10.005.

ISTA (2018). International Rules for Seed Testing 2018. ISTA Online, International Seed Testing Association.

Kaur, B., McCoy, J.-A., and Eisenstein, E. (2013). Efficient, season-independent seed germination in black cohosh (Actaea racemosa L.). Am. J. Plant Sci. 4, 77-83. https://doi.org/10.4236/ ajps.2013.45A012.

Kondo, T., Sato, C., Baskin, J.M., and Baskin, C.C. (2006). Post-dispersal embryo development, germination phenology, and seed dormancy in Cardiocrinum cordatum var. glehnii (Liliaceae s. str.), a perennial herb of the broadleaved deciduous forest in Japan. Am. J. Bot. 93, 849-859. https://doi.org/10.3732/ajb.93.6.849.

Lata, H., Bedir, E., Hosick, A., Ganzera, M., Khan, I., and Moraes, R.M. (2002). In vitro plant regeneration from leaf-derived callus of Cimicifuga racemosa. Planta Med. 68, 912-915. https://doi. org/10.1055/s-2002-34933.

Li, M., and Chen, X. (2002). Studies on seed dormancy and germination in Cimicifuga simplex Wormsk. J. Chongqing Norm. Univ. Sci. Ed. 19, 62-65.

Martin, A.C. (1946). The comparative internal morphology of seeds. Am. Midl. Nat. 36, 513. https://doi.org/10.2307/2421457.

McCoy, J.-A., Davis, J.M., Camper, N.D., Khan, I., and Bharathi, A. (2007). Influence of rhizome propagule size on yields and triterpene glycoside concentrations of black cohosh [Actaea racemosa L. syn. Cimicifuga racemosa. (L.) Nuttal] (2007). HortScience 42, 61-64. https://doi.org/10.21273/HORTSCI.42.1.61.

Nikolaeva, M.G. (1977). Factors controlling the seed dormancy pattern. In The Physiology and Biochemistry of Seed Dormancy and Germination, A.A. Khan, ed. (Amsterdam, The Netherlands: NorthHolland Publ. Co.), p. 54-74.

Pinker, I., and Schenk, R. (2018). Black Cohosh (Actaea racemosa L.). In Step Wise Protocols for Somatic Embryogenesis of Important Woody Plants, Vol. II, S.M. Jain, and P. Gupta, eds. (Berlin, Heidelberg: Springer), p. 83-93. https://doi.org/10.1007/978-3-319-790879_6.

Pinker, I., Brosowski, S., and Schenk, R. (2016). Somatic embryogenesis from stamens of Actaea racemosa L. Acta Hortic. 1132, p. 13-20. https://doi.org/10.17660/ActaHortic.2016.1113.2.

Popp, M., Schenk, R., and Abel, G. (2003). Cultivation of Cimicifuga racemosa (L.) Nuttal and quality of CR extract BNO 1055. Maturitas 44,1-7. https://doi.org/10.1016/S0378-5122(02)00343-2.

Predny, L.M., De Angelis, P., and Chamberlain, J.L. (2006). Black Cohosh, Actaea racemosa, an annotated bibliography (Asheville, NC 28804-3454). https://doi.org/10.2737/SRS-GTR-97.

Small, C.J., Chamberlain, J.L., and Nuckols, C.M. (2014). Failure of black cohosh (Actaea racemosa L.) rhizome transplants: Potential causes and forest farming implications. Agrofor. Syst. 88, 815-822. https://doi.org/10.1007/s10457-014-9727-0.

Wciślińska, B. (1977). The role of gibberellic acid $\left(\mathrm{GA}_{3}\right)$ in the removal of dormancy in Fraxinus excelsior L. seeds. Biol. Plant. 19, 370-376. https://doi.org/10.1007/BF02922734.
Received: Nov. 14, 2019

Accepted: Apr. 6, 2020

Address of authors:

I.M. Pinker*, T. Degischer, A.-Chr. Rath and R. Schenk

Humboldt-Universität zu Berlin, Albrecht Daniel ThaerInstitute, Intensive Plant Food Systems, Lentzeallee 75,

D-14195 Berlin, Germany

* Corresponding author;

E-mail: ina.pinker@cms.hu-berlin.de

Tel.: +49-30-209346297; Fax: +49-30-209346285 


\section{SUPPLEMENTAL INFORMATION}

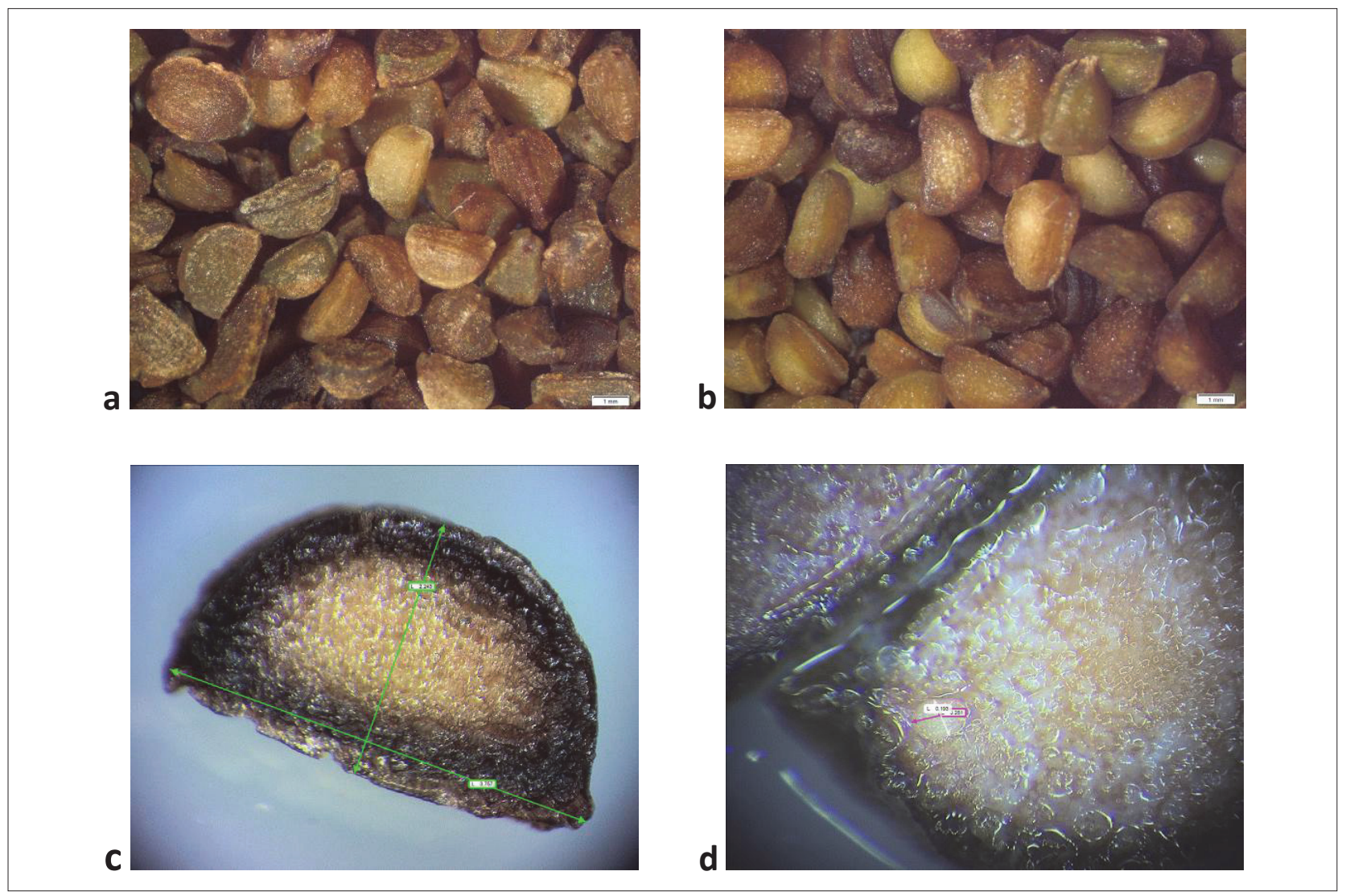

SUPPLEMENTAL INFORMATION - FIGURE S1. a: Seed sample 5 min after immersion; b: Seed sample after 2 hours of imbibition; c: Seed after 2 hours' imbibition with indication of measuring points for length and width determination; d: Halved seed after 2 hours' imbibition with heart-stage embryo and aqueous endosperm.

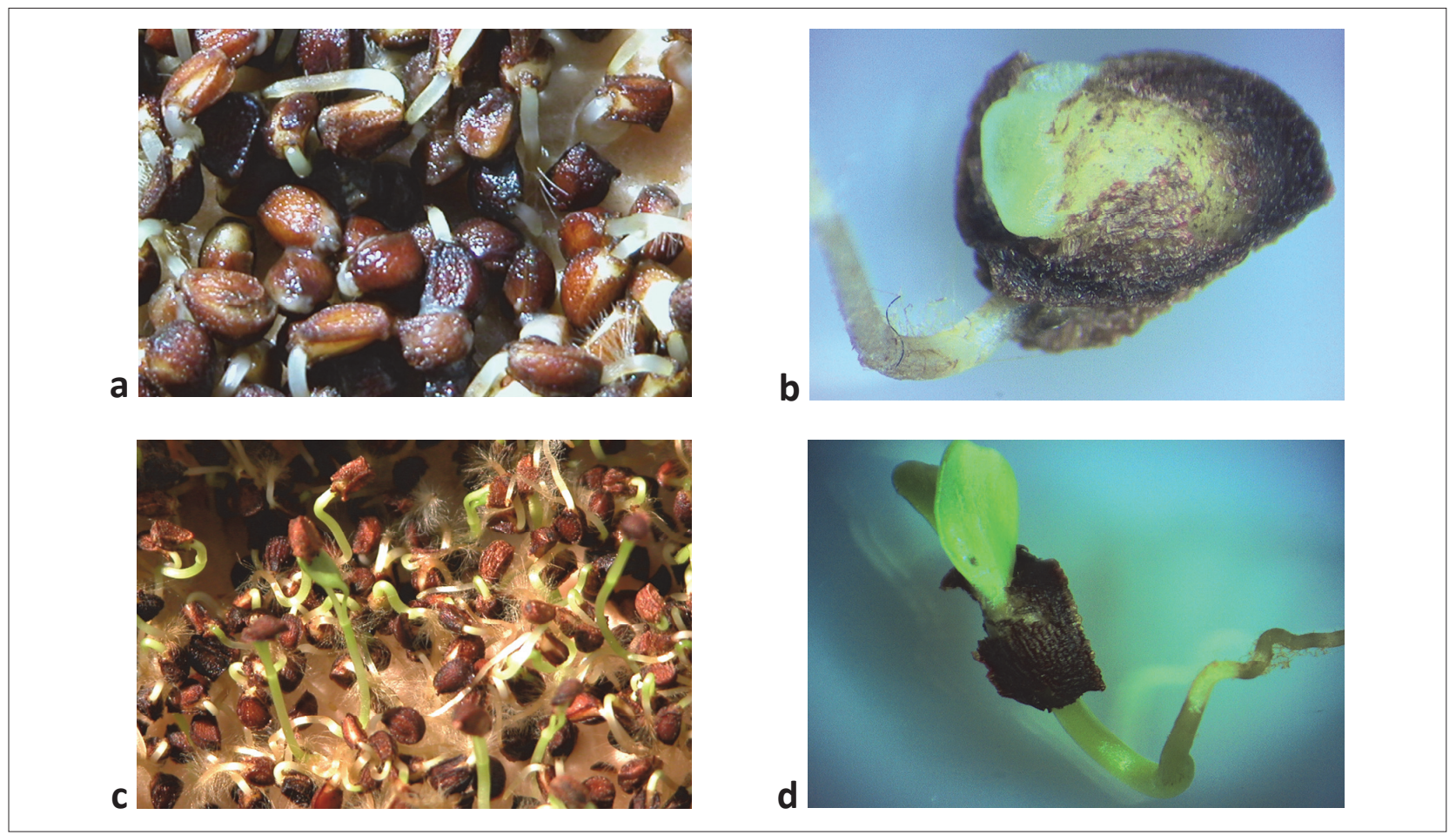

SUPPLEMENTAL INFORMATION - FigURE S2. a: Germinating seeds imbibed in $2 \mathrm{~g} \mathrm{~L}^{-1} \mathrm{GA} 3$ after 8 weeks' stratification (week $5-8$ at $14^{\circ} \mathrm{C}$ in darkness); b: Seed with radicle protrusion after 8 weeks' stratification (week $5-8$ at $14^{\circ} \mathrm{C}$ in darkness); c: Germinating seeds after 8 weeks' stratification (week $5-8$ at $14^{\circ} \mathrm{C}$ in light); d: Germinating seed after 8 weeks' stratification (week $5-8$ at $14^{\circ} \mathrm{C}$ in light). 